\title{
Detection of a Mixed Infection of Lumpy Skin Disease Virus and Foot and Mouth Disease Virus in a Calf
}

\author{
Murat Şevik ${ }^{1}$ \\ ${ }^{1}$ Department of Molecular Microbiology, Veterinary Control Institute, Konya, Turkey
}

Geliş Tarihi / Received: 18.09.2017, Kabul Tarihi / Accepted: 08.11.2017

\begin{abstract}
In this study, I investigated the possibility of dual infection with LSDV and FMDV in a 6-month-old Holstein calf which had fever, limping, nasal secretions, and lesions on the skin and vesicles on mucous membranes of the mouth. To assess presence of LSDV DNA in skin lesions, swab samples from skin were collected, and were analysed by real time PCR. Epithelium samples were collected from vesicular lesions, and were tested by the Sap Institute, Ankara for FMDV infection. Genetic characterization of the LSDV field isolate was conducted by sequencing the G-proteincoupled chemokine receptor gene segment. LSDV DNA was detected in swab samples and calf was diagnosed with FMD, serotype A. Phylogenetic analysis showed that the field isolate in this study was clustered together with other Africa, Europe and Middle East isolates. To the best of my knowledge, this is the first report on the dual infection of a calf with LSDV and FMDV.
\end{abstract}

Key words: Lumpy skin disease virus, Foot and mouth disease virus, Dual infection, calf

\section{Bir Buzağıda Lumpy Skin Disease Virusu ve Şap Haslığı Virusunun Miks Enfeksiyonunun Tespiti}

Özet: Bu çalışmada ateş, burun salgıları, topallık, deride lezyonlar ve ağız mukoz membranlarında veziküller olan 6 aylık bir Holştayn buzağıda LSDV ve FMDV'nin dual enfeksiyon olasılığı araştırılmıştır. Deri lezyonlarında LSDV varlığını araştırmak için svap örnekleri toplanmış ve real time PCR yöntemi ile analiz edilmiştir. Veziküller lezyonlardan epitelyum örnekleri toplanmış ve Şap Enstitüsü (Ankara) tarafından şap hastalığı yönünden test edilmiştir. LSDV'unun genetik karakterizasyonu, G-proteine bağlı kemokin reseptörü gen segmentinin sekans analizi ile gerçekleştirilmiştir. LSDV DNA'sı svap örneklerinde tespit edilmiş olup, buzağıya şap hastalığı (serotip A) tanısı konmuştur. Filogenetik analiz sonucu, bu çalışmada izole edilen LSDV saha suşunun, Afrika, Avrupa ve Orta Doğu izolatları ile birlikte gruplandığı görülmüştür. Bildiğim kadarıyla, bu çalışma bir buzağının LSDV ve FMDV'ları ile dual enfeksiyonu hakkındaki ilk rapordur.

Anahtar Kelimler: Lumpy skin disease virusu, Şap hastalığ virusu, Dual enfeksiyon, Buzağ

\section{Introduction}

Lumpy skin disease (LSD) is an emerging viral disease of cattle, which is characterised by fever, enlarged lymph nodes, and nodules on the skin, mucous membrane and internal organs $[5,10]$. LSD is caused by a double stranded DNA virus, classified in the genus Capripoxvirus of the family Poxviridae, and is antigenically closely related to sheep and goat poxviruses [10]. The most effective route of LSDV transmission is mechanical via biting flies [4].

Foot and mouth disease (FMD) is highly contagious disease of cloven-hoofed livestock including cattle, swine, sheep and goats, and wild animals [1]. Foot-and-mouth disease virus (FMDV), the etiological agent, is a single-stranded RNA virus belonging to the genus Aphthovirus in the family Picornaviridae, and it has seven immunologically distinct serotypes, O, A, C, SAT 1, SAT 2, SAT 3 and Asia 1 with a large number of subtypes [6]. Infection with one serotype does not confer immunity against another [9]. Transmission of FMDV mainly occurs via respiratory aerosols and direct or indirect contact with infected animals and contaminated fomites [2]. Serotypes A, O, and Asia-1 have predominated in Turkey [11]. The current study was conducted to investigate the possibility of dual infection with LSDV and FMDV in a calf which had clinical symptoms of LSD and FMD. 


\section{Material and Methods}

\section{Collection of samples}

A six month old Holstein calf was submitted to the Konya Veterinary Control Institute from a herd in the Antalya Province in the Mediterranean region of Turkey in 2016. The observed clinical signs were fever $\left(40^{\circ} \mathrm{C}\right)$, nasal secretions, limping, and lesions on the skin and vesicles on mucous membranes of the mouth. According to farmer' report, calf was not vaccinated against LSD and FMD. Firstly, epithelium samples were collected from vesicular lesions of calf, and were sent to Sap Institute, Ankara for confirmatory diagnosis of FMD and serotype determination. Furthermore, swab samples from skin were collected for LSDV detection.

\section{DNA extraction and real-time PCR}

Viral DNA extraction was carried out from the swab samples using a QIAamp Cador Pathogen Mini Kit (Qiagen, Hilden, Germany) in a QIAcube (Qiagen, Hilden, Germany). Real-time PCR was performed using $\mathrm{P} 32$ protein, encoded by open reading frame (ORF) 074, specific primers and probe designed by Bowden et al. [3].

\section{PCR and sequencing of PCR products}

PCR was performed with primers that amplified $1158 \mathrm{bp}$ of the G-protein-coupled chemokine receptor (GPCR) gene of Capripoxviruses [7]. PCR product was purified from gels with a High Pure PCR Product Purification Kit (Roche Diagnostics, Indianapolis, USA) and sequenced with the BigDye Terminator v3.1 Cycle Sequencing Kit (Applied Biosystems, USA) on an ABI 3130x1 DNAAnalyzer (Applied Biosystems, USA). Sequence analysis was performed by using ChromasPro software (Version 1.7.5, Technolysium Ltd.). Phylogenetic tree was constructed for the GPCR gene of LSDV with additional sequences from GenBank. The confidence of the neighbour-joining tree was assessed by bootstrapping, using 1000 replicates, and only values above $50 \%$ are reported.

\section{Results}

\section{Confirmatory diagnosis of FMD}

Clinical submission of the epithelium samples was identified as FMDV serotype A by Sap Institute.

\section{Detection of LSDV}

LSDV DNA was detected in swab samples.

\section{Sequence analyses}

Analysis of the GPCR gene sequences revealed that the homology between the field isolate in the present study and LSDV isolates from different regions ranged from $98.8 \%$ to $100 \%$. The deduced amino acid homology among the field isolate and previously characterised LSDV isolates ranged between $98.5 \%$ and $100 \%$.

\section{Discussion}

Lumpy skin disease was first reported in Turkey in 2013, and then the disease becomes endemic in Turkey [8]. LSDV is thought to be transmitted primarily by blood-feeding vectors [4]. Antalya Province is located in the Mediterranean region; this region has a subtropical Mediterranean climate characterised by mild and rainy winters and hot, dry summers that are suitable for the sustenance of blood-feeding insect activity and spread of arboviral infections. Therefore, the Antalya Province has a higher risk of LSDV infection.

In this study, LSDV was detected in a calf. According to farmer' report, infected calf was not vaccinated against LSD, whereas other animals in the herd were vaccinated against LSD and clinical symptoms were not observed in vaccinated animals. In Turkey, vaccination was carried out using the sheep and goat pox vaccine. Vaccination is the most effective way to control further spread of LSDV. Calves from vaccinated mothers should be vaccinated between 3 to 4 months of age [14]. The characteristic clinical signs of LSD are fever, nasal and pharyngeal secretions, loss of appetite, nodules in the skin and enlarged lymph nodes [5,10]. In this study, fever of $40^{\circ} \mathrm{C}$, nasal secretions, and lesions on the skin were observed in infected calf. Clinical signs can change depend on age, breed of cattle and immune status at the time of infection [15].

The phylogenetic tree based on the GPCR gene sequences revealed that the field isolates in this study clustered together with other isolates from Africa, Europe and the Middle East (Fig. 1). This result is in agreement with previous report [12]. 


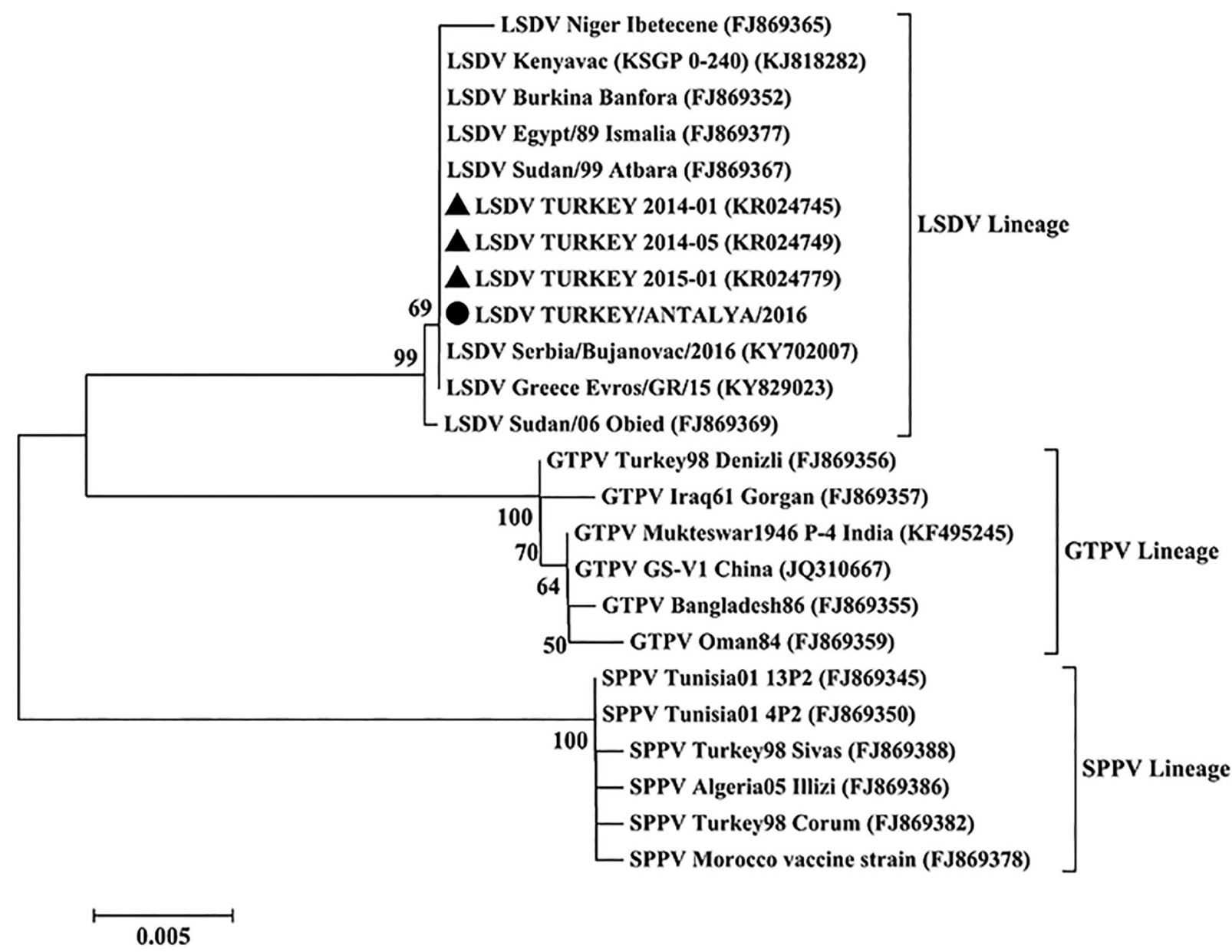

Figure 1. Phylogenetic tree constructed based on nucleotide sequences of the GPCR gene (1074 bp) showing the genetic relationships between LSDV isolate in this study and other virus isolates. The sequence obtained in this study is marked with round black spot $(\bullet)$ and previous Turkish isolates are marked with black triangle $(\boldsymbol{\Delta})$.

Foot and mouth disease remains an important disease in Turkey, and its control is mainly based on vaccination. Routine FMD vaccination is performed using quadrivalent vaccine which incorporates serotypes O, A and Asia 1 (O Tur 07, A Tur 16, A NEP 84 and Asia-1 Tur 15 strains). In this study, infected calf had not been vaccinated against FMD, and calf was diagnosed with FMD, serotype A by Sap Institute. According to farmer' report, mother of the infected calf was vaccinated against FMD, and this infected calf received colostrum. Antibodies against FMDV transmitted through maternal colostrum protect calves until 2 months of age [13]. However, in this study infected calf was 6 months of age. Calves from vaccinated mothers should be vaccinated at 2 months of age, whereas calves from unvaccinated mothers should be vaccinated at 2 weeks of age [11].
The results of this study indicate that dual infection with LSDV and FMDV may have occurred. Young animals are more susceptible to these infections than adults, because their immune systems aren't fully functional. Vaccination is the most effective way to control the spread of LSDV and FMDV. Therefore, young animals should be vaccinated against LSDV and FMDV infections.

\section{References}

1. Alexandersen S, Mowat N, (2005). Foot-and-mouth disease: host range and pathogenesis. Curr Top Microbiol Immunol. 288, 9-42.

2. Bates TW, Thurmond MC, Carpenter TE, (2001). Direct and indirect contact rates among beef, dairy, goat, sheep, and swine herds in three California counties, with reference to control of potential foot-and-mouth disease transmission. Am J Vet Res. 62, 1121-1129. 
3. Bowden TR, Babiuk SL, Parkyn GR, Copps JS, Boyle DB, (2008). Capripoxvirus tissue tropism and shedding: A quantitative study in experimentally infected sheep and goats. Virology. 371, 380-393.

4. Chihota CM, Rennie LF, Kitching RP, Mellor PS, (2003). Attempted mechanical transmission of lumpy skin disease virus by biting insects. Med Vet Entomol. 17, 294-300.

5. Davies FG, Krauss H, Lund J, Taylor M, (1971). The laboratory diagnosis of lumpy skin disease. Res Vet Sci. 12, 123127.

6. Grubman MJ, Baxt B, (2004). Foot-and-mouth disease. Clin Microbiol Rev. 17, 465-493.

7. Le Goff C, Lamien CE, Fakhfakh E, Chadeyras A, AbaAdulugba E, Libeau G, Tuppurainen E, Wallace DB, Adam T, Silber R, Gulyaz V, Madani H, Caufour P, Hammami S, Diallo A, Albina E, (2009). Capripoxvirus G-proteincoupled chemokine receptor: a host-range gene suitable for virus animal origin discrimination. J Gen Virol. 90, 1967-1977.

8. Office International des Epizooties (OIE), 2013: OIE disease information. Available at: http://www.oie.int/wahis_2/public/wahid.php/Reviewreport/Review?reportid=14106 (accessed on 25 August 2017).

9. Office International des Epizooties (OIE), (2017). Foot and Mouth Disease (Infection with Foot and Mouth Disease
Virus). In Manual of Diagnostic Tests and Vaccines for Terrestrial Animals. OIE, Paris, 1-32. Available at: http:// www.oie.int/fileadmin/Home/eng/Health_standards/ tahm/2.01.08_FMD.pdf (accessed on 25 August 2017).

10. Office International des Epizooties (OIE), (2017). Lumpy skin disease. In Manual of Diagnostic Tests and Vaccines for Terrestrial Animals. OIE, Paris, 1-13. Available at: www.oie.int/fileadmin/Home/eng/Health_standards/ tahm/2.04.14_LSD.pdf (accessed on 25 August 2017).

11. Şap Enstitüsü, (2017). Türkiye'de Şap Hastalı̆̆l. Available at: http://vetkontrol.tarim.gov.tr/sap/Menu/34/TurkiyedeSap-Hastaligi (accessed on 25 August 2017).

12. Şevik M, Doğan M, (2017). Epidemiological and Molecular Studies on Lumpy Skin Disease Outbreaks in Turkey during 2014-2015. Transbound Emerg Dis. 64, 1268-1279.

13. Şenel E, Ulutürk S, Boz C, (1989). Buzağılarda şap aşısi ile aşılama zamanının tespiti. 1. Uluslararası Şap Sempozyumu, Ankara. pp. 191-194.

14. Tuppurainen E, Galon N, (2016). Lumpy Skin Disease. Current Situation in Europe and Neighbouring Regions and Necessary Control Measures to Halt the Spread in SouthEast Europe. OIE Regional Commission. 1-12.

15. Tuppurainen E, Alexandrov T, Beltrán-Alcrudo D, (2017). Lumpy skin disease field manual -A manual for veterinarians. FAO Animal Production and Health Manual. 20, 1-60. 